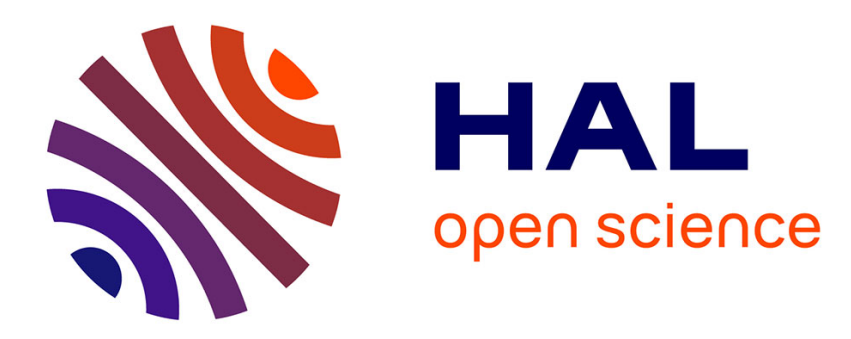

\title{
SPALL STRENGTH AND FAILURE WAVES IN GLASS
}

\author{
N. Brar, Z. Rosenberg, S. Bless
}

\section{To cite this version:}

N. Brar, Z. Rosenberg, S. Bless. SPALL STRENGTH AND FAILURE WAVES IN GLASS. Journal de Physique IV Proceedings, 1991, 01 (C3), pp.C3-639-C3-644. 10.1051/jp4:1991389 . jpa-00250534

\section{HAL Id: jpa-00250534 https://hal.science/jpa-00250534}

Submitted on 1 Jan 1991

HAL is a multi-disciplinary open access archive for the deposit and dissemination of scientific research documents, whether they are published or not. The documents may come from teaching and research institutions in France or abroad, or from public or private research centers.
L'archive ouverte pluridisciplinaire HAL, est destinée au dépôt et à la diffusion de documents scientifiques de niveau recherche, publiés ou non, émanant des établissements d'enseignement et de recherche français ou étrangers, des laboratoires publics ou privés. 


\title{
SPALL STRENGTH AND FAILURE WAVES IN GLASS
}

\author{
N.S. BRAR, Z. ROSENBERG ${ }^{(1)}$ and S.J. BLESS \\ Impact Physics Laboratory, University of Dayton Research \\ Institute, 300 College Park, Dayton, OH 45469-0182, U.S.A
}

\begin{abstract}
Résumé : Une série d'expériences d'impacts de plaques sur des verres sodo-calciques et pyrex a été réalisée, pour étudier les ondes de rupture, récemment mises en évidence par Kancel et al /1/. L'existence de ces ondes est déduite d'observation de figures d'interaction d'ondes et de mesures de contrainte d'écaillage de verres sodo-calciques et pyrex, à l'avant et à l'arrière de ces fronts d'onde. Les verres sodo-calciques et pyrex ont des comportements très différents dans le domaine élastique de compression par choc.
\end{abstract}

Abstract - We performed a series of plate impact experiments on soda lime and pyrex glasses to investigate failure waves, which have been recently reported by Kanel et al /1/. The existence of these waves is inferred from observations of wave interaction patterns and by measuring spall strength of soda lime glass and pyrex, in front and behind, these wave fronts. Soda lime and pyrex glasses display quite different behavior in the elastic range of shock loading.

\section{INTRODUCTION}

The response of glasses to shock loading has been the subject of vigorous research in the last two decades $/ 2-6 /$. These studies report data on the loading and unloading behavior of different glasses; soda-lime, pyrex, borosilicates, fused quartz and crystalline quartz. One of the important conclusions of these investigations is that there are basically two groups of glasses: 1) the "normal" ones that behave as elasto-plastic similar to that observed in metals and 2) the "anomalous" glasses, which exhibit a ramping elastic wave due to a decrease of the bulk modulus with increasing shock pressure (up to $30 \mathrm{kbar}$ ). Soda-lime glass is a typical representative for the "normal" glasses whereas pyrex falls in the "anomalous" family.

In a recent study we found that the spall strength of soda-lime glass is very high for shock levels below the Hugoniot Elastic Limit (HEL) (64 kbar) while above the HEL the spall strength is almost zero for this material /7/. Pyrex (HEL $75 \mathrm{kbar} / 8 /$ ) showed similar characteristics which prompted us to assign a meaning of total failure to the HEL of these two materials /9/.

Kanel et al / $1 /$ have reported free surface velocity measurements (using VISAR) of shock loaded K19 glass (similar to soda lime glass) from which they concluded that a third wave (which they identify as failure wave) propagates behind the elastic and plastic wave fronts. The failure wave propagates at about $1.5-2 \mathrm{~mm} / \mu \mathrm{s}$ and represents the total fracture or failure of the specimen. The purpose of the present work was to explore the existence of the fracture waves in glass specimens 
by monitoring wave interactions with failure wave and by measuring the spall strength in front and behind the wave, using manganin stress gauges.

\section{EXPERIMENTAL METHOD}

Soda lime glass plates ( $5.7 \mathrm{~mm}$ thick) were obtained locally. The density and longitudinal wave velocity were $2.5 \mathrm{~g} / \mathrm{cm}^{3}$ and $5.84 \mathrm{~mm} / \mu \mathrm{s}$, respectively. Pyrex plates, obtained from Corning Glass Works, were $6.2 \mathrm{~mm}$ thick. The pyrex density was $2.23 \mathrm{~g} / \mathrm{cm}^{3}$ and longitudinal wave velocity was $5.6 \mathrm{~mm} / \mu \mathrm{s}$. Commercial manganin gauges (Type LM-SS-125CH-048) were purchased from Micro-Measurements, Raleigh, NC.

Manganin gauges were embedded at the interface between the glass plates and 13-mm thick PMMA (Polycast Acrylic, Stamford, CT) plates as shown in Figure 1. Two types of experiments were performed: (I) wave interaction type similar to Kanel et al $/ 1 /$, in which the interaction of the failure wave with the release wave from the glass-PMMA interface was monitored, and (II) spall type, where the interaction of the release waves form the back of the impactor and from the glassPMMA interface were intended to spall the glass target plate. In these experiments the thickness of the impactors were chosen as to whether the spall plane is behind or in front of the failure wave (Figure 2a). In the first type of experiments we used thick copper impactor plates, whereas in the second type both aluminum and glass impactors were employed. Impactor velocities were set to obtain peak shock stress in both the elastic and inelastic range of the two materials.

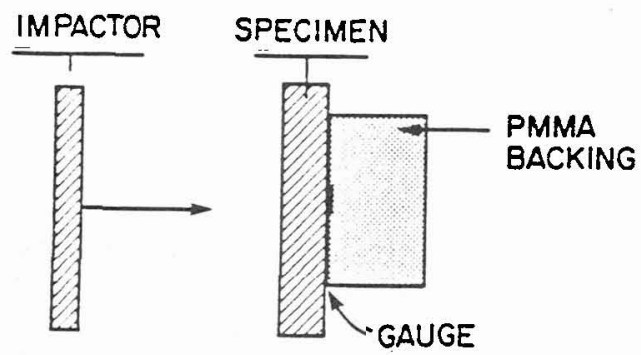

(a)

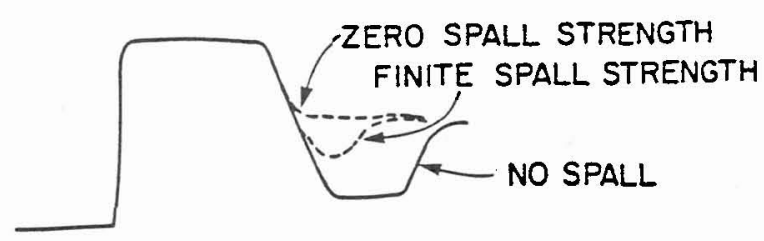

(b)

Figure 1. (a) Schematic of impactor and target configurations, (b) typical gauge records in spall experiments with manganin gauges.

A total of nine experiments were performed using the $50-\mathrm{mm}$ gas/powder gun at the University of Dayton Research Institute. The details of the experiments are summarized in Table 1. The calibration of manganin gauges used in the present experiments was reported under shock loading and unloading $/ 10,11 /$. The interpretation of the spall signals present in manganin gauge profile was based on earlier studies $/ 7,12 \%$.

\section{RESULTS AND DISCUSSION}

Manganin gauge profile from a Type I experiment (7-1628) is shown in Figure 2(b). In this experiment release wave from the glass-PMMA interface interacts with the failure wave originating at the impactor-target (glass) interface. There is a small increase in stress (point A) as a result of the reflection of the release wave from the material with lower impedance (comminuted glass behind the failure wave front). This duplicates the finding of Kanel et al $/ 1 \%$. The arrival of the small increase in stress corresponds to failure wave velocity of about $1.7 \pm 0.2 \mathrm{~mm} / \mu \mathrm{s}$. 
Further evidence of the existence of failure waves in glass comes from spall (type II) experiments. We reported earlier that the spall strength of soda lime glass is zero for shock stress of about $70 \mathrm{kbar}$ (above HEL) /7/. In that experiment (7-0889) we impacted a 5.7-mm thick soda lime glass target with a $3.9 \mathrm{~mm}$ aluminum flyer at a velocity of $906 \mathrm{~m} / \mathrm{s}$. Manganin gauge profile is shown in Figure 3(a). The spall plane in this experiment happened to be behind the failure wave. In the present study we repeated this experiment with a 2.4-mm thick aluminum flyer (7-1533) and found that there is no spall signal in the manganin gauge profile, as shown in Figure $3(\mathrm{~b})$. The spall plane in this experiment was in front of the failure wave. There is a clear evidence from the results of these two experiments that the spall strength of soda lime glass depends on the location of the
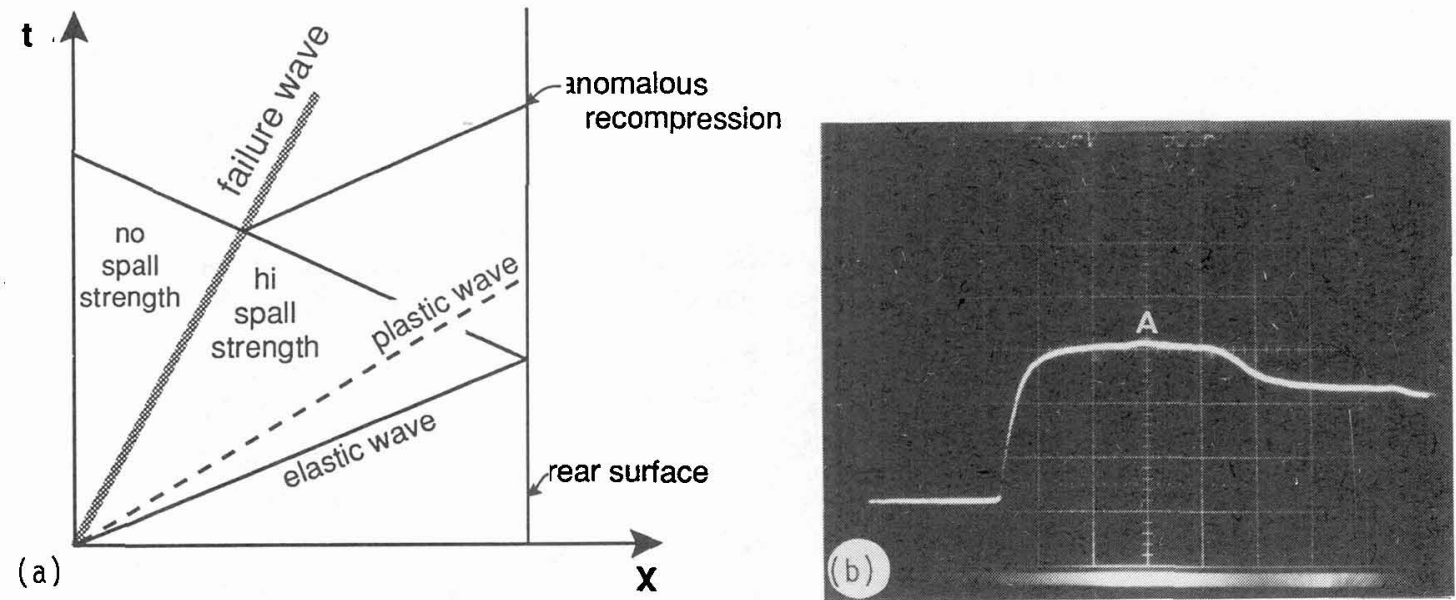

Figure 2. (a) $x$-t diagram showing propagating elastic, plastic, and failure waves. The interaction of release waves with the failure wave results in anomalous compression, (b) Gauge profile from experiment 7-1628 showing a small recompression (point A) on top of peak stress. Scales: $0.5 \mathrm{v} / \mathrm{div}$. and $0.5 \mu \mathrm{s} / \mathrm{div}$.
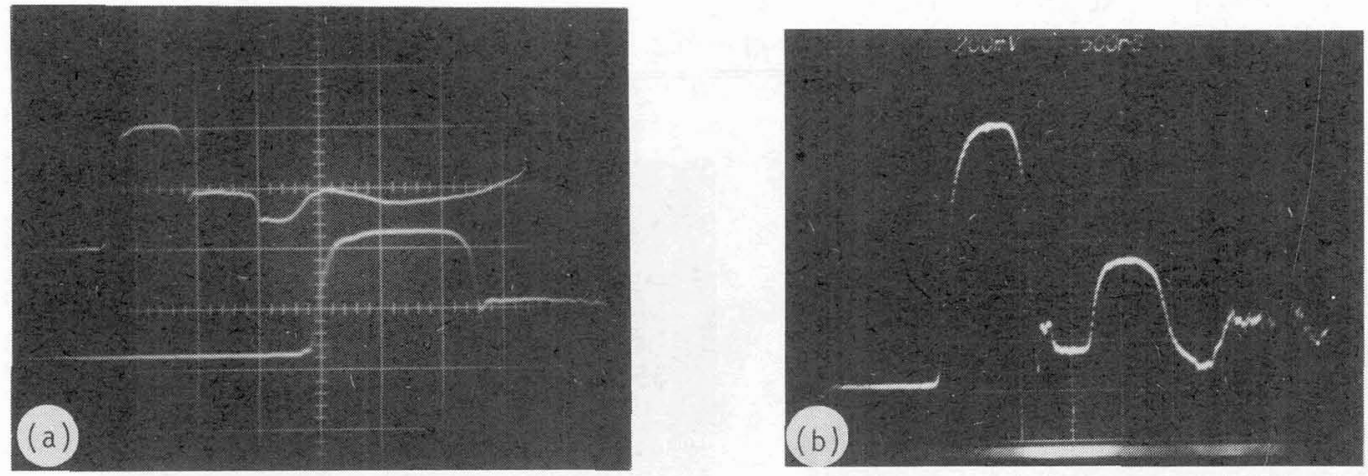

Figure 3. (a) Gauge profile from experiment 7-0889 showing zero spall strength. Scales: 0.5 v/div., $1 \mu \mathrm{s} /$ div. (upper trace), and $0.5 \mu \mathrm{s} /$ div. (lower trace), (b) Gauge profile from experiment 7-1533 showing complete release from the back of impactor and no spall signal. Scales $0.2 \mathrm{v} / \mathrm{div}$. and 0.5 $\mu \mathrm{s} /$ div. 
Table 1. Summary of Experimental Data and Results

\begin{tabular}{|c|c|c|c|c|c|}
\hline Shot no & $\begin{array}{l}\text { Impactor/ } \\
\text { Thickness } \\
(\mathrm{mm})\end{array}$ & $\begin{array}{l}\text { Impactor } \\
\text { Velocity } \\
(\mathrm{m} / \mathrm{s})\end{array}$ & $\begin{array}{l}\text { Target/ } \\
\text { Thickness } \\
(\mathrm{mm})\end{array}$ & $\begin{array}{l}\text { Shock } \\
\text { stress } \\
\text { (kbar) }\end{array}$ & $\begin{array}{l}\text { Gauge signal } \\
\text { remarks }\end{array}$ \\
\hline $7-1531$ & $\mathrm{Cu} / 6.0$ & 864 & $\begin{array}{l}\text { Soda lime } \\
\text { glass } / 5.7\end{array}$ & 85 & $\begin{array}{l}\text { small } \\
\text { recompression } \\
\text { on top of peak } \\
\text { stress }\end{array}$ \\
\hline $7-1628$ & $\mathrm{Cu} / 8.0$ & 831 & $\begin{array}{l}\text { Soda lime } \\
\text { glass } / 5.7\end{array}$ & 81 & $\begin{array}{l}\text { small } \\
\text { recompression } \\
\text { on top of peak } \\
\text { stress }\end{array}$ \\
\hline $7-0889$ & $\mathrm{Al} / 3.9$ & 906 & $\begin{array}{l}\text { Soda lime } \\
\text { glass } / 5.7\end{array}$ & 68 & $\begin{array}{l}\text { spall signal with } \\
\text { zero strength }\end{array}$ \\
\hline $7-1533$ & $\mathrm{Al} / 2.4$ & 917 & $\begin{array}{l}\text { Soda lime } \\
\text { glass } / 5.7\end{array}$ & 69 & $\begin{array}{l}\text { no spall signal } \\
\text { full unloading }\end{array}$ \\
\hline 7-0892 & $\mathrm{Al} / 3.1$ & 745 & $\begin{array}{l}\text { Soda lime } \\
\text { glass } / 5.7\end{array}$ & 57 & $\begin{array}{l}\text { no spall signal } \\
\text { full unloading }\end{array}$ \\
\hline $7-1612$ & $\mathrm{Al} / 5.2$ & 728 & $\begin{array}{l}\text { Soda lime } \\
\text { glass } / 5.7\end{array}$ & 55 & $\begin{array}{l}\text { spall signal with } \\
\text { zero strength }\end{array}$ \\
\hline $7-1615$ & $\mathrm{Al} / 4.8$ & 741 & $\begin{array}{l}\text { Soda lime } \\
\text { glass } / 5.7\end{array}$ & 57 & $\begin{array}{l}\text { spall signal with } \\
\text { zero strength }\end{array}$ \\
\hline $7-1623$ & $\begin{array}{l}\text { Soda lime } \\
\text { glasss } / 4.8\end{array}$ & 681 & $\begin{array}{l}\text { Soda lime } \\
\text { glass } / 5.7\end{array}$ & 49 & $\begin{array}{l}\text { spall signal with } \\
\text { zero strength }\end{array}$ \\
\hline $7-1616$ & $\mathrm{Al} / 4.8$ & 685 & $\begin{array}{l}\text { Pyrex } \\
\text { glass/6.2 }\end{array}$ & 52 & $\begin{array}{l}\text { no spall signal } \\
\text { full unloading }\end{array}$ \\
\hline
\end{tabular}
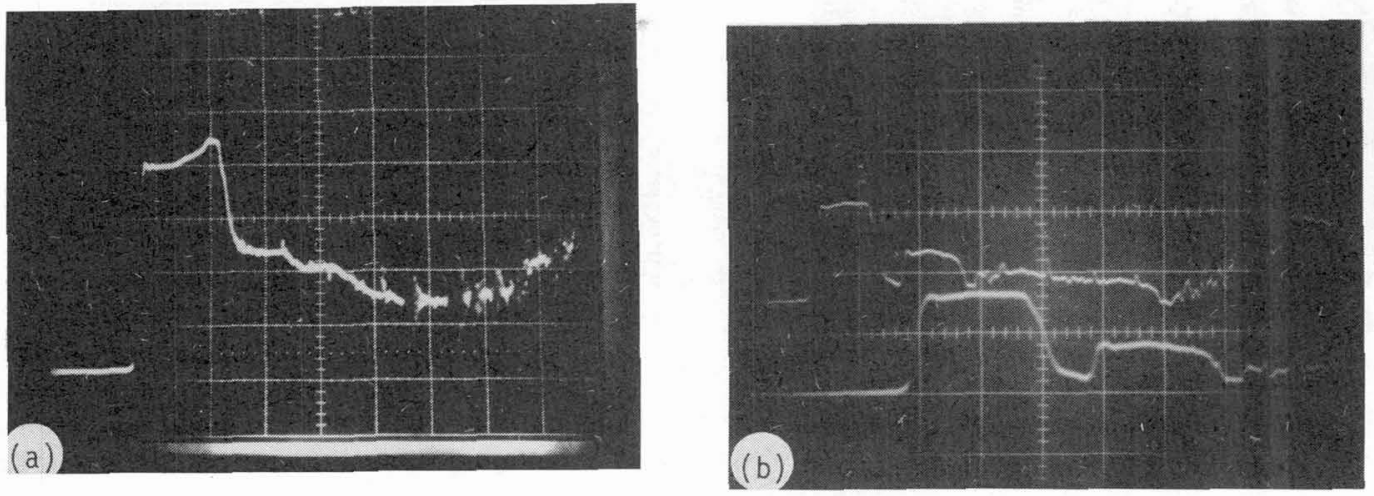

Figure 4. (a) Gauge profile from experiment 7-1612 showing zero spall strength. Scales 0.2 v/div. and $1.0 \mu \mathrm{s} /$ div., (b) gauge profile from experiment 7-0892 showing complete release and no spall signal. Scales $0.5 \mathrm{v} / \mathrm{div} ., 1 \mu \mathrm{s} /$ div. (upper trace) and $0.5 \mu \mathrm{s} /$ div. (lower trace). 
spall plane with respect to the propagating failure wave, originating at the impactor-target interface.

In order to observe whether a failure wave in soda lime glass occurs for the peak stresses in the elastic range (below HEL), we analyze the data form three experiments (7-1612, 7-1615, 7-1623). Manganin gauge profiles from these experiments (Figure 4a) show unambiguously the spall strength of soda lime glass is almost zero. Impactor thicknesses in these experiments were chosen so that the spall plane is behind the failure wave. We compare this result with the data reported earlier /7/ where the peak shock stress was also in the elastic range (7-0892), but the spall plane was in front of the failure wave. Spall strength in experiment 7-0892 was determined to be more than 30 kbar (Figure 4b). Thus the results on the spall strength of soda lime glass for the same shock stress in the elastic range are drastically different. These differences can be resolved on the basis of the existence of failure waves in soda lime glass for shock stresses below and above HEL.

An interesting feature is present in manganin gauge profiles shown in Figures 4(a) and (b). The shock levels in these profiles are not constant, but a gradual increase in the shock level is seen. We interpret this increase to be due to the reflection of the release wave fan from the glass-PMMA interface from the advancing failure wave in glass.

Yeshurun et al $/ 8 /$ have already demonstrated that the spall strength for pyrex is zero for $\sigma_{\text {shock }}>$ HEL and nonzero for $\dot{\sigma}_{\text {shock }}<\mathrm{HEL}$. We investigated the existence of failure wave within the elastic range in pyrex by repeating experiment 7-1615 with pyrex target. Figure 5 shows the gauge record in experiment 7-1616 (impact velocity of $685 \mathrm{~m} / \mathrm{s}$, aluminum 6061-T6 impactor, 4.8-mm thick). It is clearly seen that the pyrex target did not spall. This strongly suggests that no failure wave was produced in this material in the elastic range (at least to $52 \mathrm{kbar}$ ). This basic difference between the two glasses may be related to the differences in their compressibility, which is responsible for the normal-anomalous behavior of the two materials. Another explanation may lie in the fact that soda lime glass is a "structureless" glass, whereas pyrex contains two phases. Differences in failure wave propagation may also be related to the different crack initiation and growth observed in /13/ for pyrex and soda lime glass impacted by steel spheres. It turns out that after impact a large number of splinter cracks initiate beneath the impact site in soda lime glass while no splinter cracks occur in pyrex.

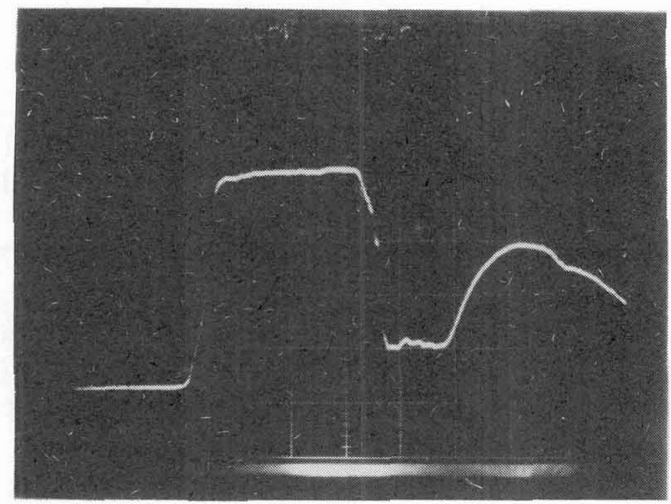

Figure 5. Gauge profile from experiment 7-1616 on Pyrex glass showing complete release and no spall. Scales $0.2 \mathrm{v} / \mathrm{div}$. and $0.5 \mu \mathrm{s} / \mathrm{div}$. 


\section{CONCLUSIONS}

Our interpretation of these experiments is summarized in Figure 2(a). Failure waves in shock loaded glass specimens were detected using manganin stress gauges in spall experiments. These waves exist in soda lime glass even for elastic loading but not in pyrex glass.

\section{ACKNOWLEDGEMENTS}

This work was supported by the Army Research Office under contract DAAL-03-88-K-0203. Mr. Mark Laber is thanked for helping with the experimental effort.

\section{REFERENCES}

/1/ Kanel G. I., Rasorenov S. V., and Fortov V. E., preprint, paper submitted to 1991 APS Shock Compression of Condensed Matter, Topical Conference, June 1991, Williamsburg, VA.

12/ Wackerle J., J. Appl. Phys. 33 (1962) 922.

13/ Dremin A. N. and Adadurov A. G., Sov. Phys. Solid State 6 (1964) 1379

14/ Gibbons R. V. and Ahrens T. J., J. Geophys. Res. 76 (1970) 5489.

15/ Kanel G. I., Molodets A. M., and A. N. Dremin, Combust. Explos. Shock Waves, 13 (1977) 772.

16/ Cagnoux J., in the Proc. of APS Conf. on Shock Waves in Condensed Matter, 1981 ed. by J. Nellis, L. Seaman, and R. A. Graham, American Institute of Physics (1982).

/7/ Rosenberg Z., Bless S. J., and Yaziv D., J. Appl. Phys. 58 (9185) 3249.

/8/ Cagnoux J. and Longy F., J. de Physique 49 (1988) C3-3

19/ Yeshurun Y., Rosenberg G., and Rosenberg Z., Proc. of APS Topical Conf. on Shock Waves in Condensed Matter, Spokane, WA, July 1985, Editor Y. M. Gupta, Plenum Press, N.Y.

/10/ Rosenberg Z., Yaziv D., and Partom Y., J. Appl. Phys. 51 (1980) 3702.

/11/ Yaziv D., Rosenberg Z., and Partom, Y., J. Appl. Phys. 55 (1980) 6055.

112/ Yaziv D., Bless S. J., and Rosenberg Z., J. Appl. Phys. 58 (1985) 3415.

/13/ Knight C. G., Swain M. V., and Chaudhri M. M., J. Mat. Sci. 12 (1977) 1573. 